\title{
Food-frequency questionnaires: a review of their design, validation and utilisation
}

\author{
J. E. Cade ${ }^{1 *}$, V. J. Burley ${ }^{1}$, D. L. Warm ${ }^{2}$, R. L. Thompson ${ }^{2}$ and B. M. Margetts ${ }^{2}$ \\ ${ }^{1}$ Nutritional Epidemiology Group, University of Leeds, Leeds LS2 9JT, UK \\ ${ }^{2}$ Institute of Human Nutrition, University of Southampton, Southampton SO16 6YD, UK
}

\begin{abstract}
A review of the literature concerning the design, utilisation and validation of food-frequency questionnaires (FFQ) has been carried out using a semi-systematic approach to obtaining, reviewing and extracting data from articles. Databases were searched from 1980 to 1999. The present review identified 227 validation (from 1980 to September 1999) and 164 utilisation (for 1998 only) studies. A number of design issues have been evaluated through the present review. These include: the need to consider how portion sizes have been described, self-defined giving higher mean correlations; how an FFQ was administered, interviewer-administered giving higher mean correlations for some nutrients; how many items to include on an FFQ, those with the largest number of items having higher correlations. Validation techniques were described. Most validation studies involved comparing an FFQ against another dietary assessment method; only $19 \%$ compared an FFQ to a biomarker. Measurement differences were most commonly assessed by correlation coefficients as opposed to other more appropriate methods. Mean correlation coefficients were highest for $\mathrm{Ca}$ and fat, and lowest for vitamin $\mathrm{A}$ and vegetables. The utilisation studies showed that FFQ were most commonly used in cross-sectional surveys, with ninety-three of the FFQ being designed to be disease-specific. The present review results were presented to a group of experts and a consensus arrived at concerning the development, validation and use of FFQ. Recommendations derived from the consensus arising from the literature review are presented as an appendix to the present paper.
\end{abstract}

Food-frequency questionnaires: Validation: Reproducibility

\section{Introduction}

During the 1950s and 1960s nutritionists started to develop questionnaires for the assessment of habitual food intake based on a checklist of foods consumed over a set time period because of problems encountered with $24 \mathrm{~h}$ recall techniques and weighed inventories. After further refinement, revision and appraisal during the 1980s and 1990s, food-frequency questionnaires (FFQ) have become one of the key research tools in nutrition epidemiology. However, despite considerable advantages in terms of ease of administration and analysis, FFQ may be limited in their usefulness and, through poor design and inappropriate use, may not yield the required information. No dietary method can measure dietary intake without error (Margetts \& Nelson, 1997) so it is important that sources of error are taken into account. No formal systematic review of the FFQ method has been carried out to date. The present study has brought the results of research together to evaluate the method and assess 'best practice' for further studies.

\section{Methodology}

A systematic review approach (Chalmers \& Altman, 1995) was developed to identify relevant studies describing the design, evaluation and/or use of FFQ. The definition of an FFQ was specified for the purposes of the search as 'any list of one or more foods with frequency of intake categories'. However, since the focus of the present review was the design, validation and utilisation of FFQ, papers were excluded in which the results of the FFQ were combined with another dietary assessment technique, as for example in the dietary history method. Questionnaires that assessed only vitamin and mineral supplement intakes, alcohol, or contaminants (such as heavy metals) were excluded, as were articles written in languages other than English.

\footnotetext{
Abbreviations: FFQ, food-frequency questionnaire; OR, odds ratio.

* Corresponding author: Dr J. E. Cade, fax +44 113343 3470, email j.e.cade@leeds.ac.uk
} 
A comprehensive search procedure was developed which involved searching electronic databases including Medline (http://medline.cos.com/), Embase (www.embase.com/), Cancerlit (www.cancer.gov/search/cancer_literature/), CAB Abstracts (www.cabi-publishing.org/Products/Database/ Abstracts/Index.asp) and Dissertation Abstracts (http://library.dialog.com/bluesheets/html/bl0035.html) and the online Dietary Assessment Calibration/Validation Register (www-dacv.ims.nci.nih.gov/). The databases were searched from 1980 to September 1999. Hand searches of published conference proceedings, key nutrition journals and reference lists of retrieved articles were also undertaken. Personal contact with experts was also undertaken to identify any results not in the literature to date, for example through the Nutritional Epidemiology Group and at a small number of conferences.

The papers to be included in the present review were identified using specific search terms based on the Medical Subject Headings (MeSH) terms and keywords. Searches were carried out for the terms 'food frequency questionnaires', 'reproducibility', 'validity/validation', 'diet-studytechniques' and 'calibration'. All references were downloaded into the computerised bibliographic program Reference Manager (Research Information Systems, 1999) which facilitated the handling of the large numbers of publications obtained.

Aspects of utilisation were assessed from references published in 1998. A 1-year sample was thought to be adequate to generate data on the way FFQ are currently being used since there were a large number of references which had used FFQ.

Standard data-extraction forms were developed and included information on general aspects of the study, features of the FFQ, details of associated validation and utilisation papers, and results in terms of correlation coefficients. Information from the references identified by the search was entered onto a Microsoft Access (version 2) database which broadly categorised papers into three types: validation, reproducibility, or utilisation. One member of the team (D. W.) carried out the data extraction although any queries as to whether a study should be included or not were referred to other members of the team. Studies were not assessed for quality before inclusion in the database. Therefore all relevant studies meeting the inclusion criteria were included and quality was not judged at this stage.

The large number of studies which were identified by the search and the widely varying nature of the studies in design and presentation led to some difficulties in terms of standardisation of data extraction. It is possible that some papers were missed out from the present review. The aim was to ensure that all the key papers (published and unpublished) were identified; nevertheless some may have been missed.

Following extraction of the data, the initial results were presented at a meeting of the Nutrition Epidemiology Group, a group of UK national experts in the field, which was held at King's College in London, December 1999. The group members agreed to comment on the text of the consensus document being prepared. The consensus document was also sent to a number of international experts.
Following receipt of these comments the consensus document was amended, taking the whole body of evidence into account (Cade et al. 2002).

The purpose of the present paper is to describe the results of the review of the literature on FFQ.

\section{Results}

The searches yielded 1982 references of which 779 hard copies of papers were obtained. This number included review articles and a number of publications that originated from the same study. Finally, 227 validation studies (196 single studies and thirty-one groups of studies) and 164 utilisation studies (156 single studies and eight groups of studies) were identified, and data from these studies were extracted.

\section{Validation studies}

Validation of the FFQ method is important to assess the degree to which the questionnaire measures items (foods or nutrients) for which it has been designed. Incorrect information may lead to false associations between dietary factors and diseases or disease-related markers. The issues involved with validation procedures in dietary studies are discussed in more detail in Burema et al. (1988) and Nelson (1997).

\section{Background information on the validation studies}

The 227 validation studies identified originated from thirty different countries, with most (102) originating in the USA (Table 1). Of the studies, $183(81 \%)$ had samples drawn from the general population. The present review also showed that $45 \%$ of validation studies used a modified version of a previously developed questionnaire. Of the 104 questionnaires adapted from previous FFQ, twenty-six were adapted from the Block questionnaire (Block et al. 1986) and twenty-eight were adapted from the Willett questionnaire (Willett et al. 1985). Examples of validation papers which have used as a basis the Block questionnaire include: Brown \& Griebler (1993); Tylavsky \& Sharp (1995); Eck et al. (1996); Hartman et al. (1996); Sawaya et al. (1996); Baranowski et al. (1997); Marshall et al. (1997); Riboli et al. (1997b); Kuriniji et al. (1998); Lemaitre et al. (1998); Potischman et al. (1998a); MayerDavis et al. (1999). Those which have used the Willett questionnaire include: Stein et al. (1992); Byers et al. (1993); Ajani et al. (1994); Basch et al. (1994); Bingham \& Day (1997); Wirfalt et al. (1998); Bell et al. (1999); Tucker et al. (1999). The numbers of validation papers published increased in the mid-1990s, suggesting that researchers appreciated the need to validate their methods (Fig. 1).

\section{Description of the food-frequency questionnaires used in the validation studies}

Of the FFQ, 115 were designed to assess foods or food groups and 166 assessed nutrients. Seventy-five questionnaires assessed single nutrients or food groups (for 
Table 1. Countries represented undertaking food-frequency questionnaire validation studies

\begin{tabular}{lr}
\hline Country & Number of papers \\
\hline USA & 102 \\
UK & 24 \\
Sweden & 15 \\
Australia & 14 \\
Canada & 9 \\
Netherlands & 9 \\
Italy & 7 \\
Denmark & 6 \\
Finland & 5 \\
New Zealand & 5 \\
Japan & 4 \\
Norway & 4 \\
India & 2 \\
China & 2 \\
France & 2 \\
Germany & 2 \\
Singapore & 2 \\
Belgium, Finland, Germany & \\
(combined study) & 1 \\
Brazil & 1 \\
Greece & 1 \\
Hong Kong & 1 \\
Iran & 1 \\
Ireland & 1 \\
Mali & 1 \\
Mexico & 1 \\
Switzerland & 1 \\
Philippines, Guatemala, Tanzania & (combined study) \\
Poland & 1 \\
South Africa & 1 \\
Spain & 1 \\
\hline & \\
\hline
\end{tabular}

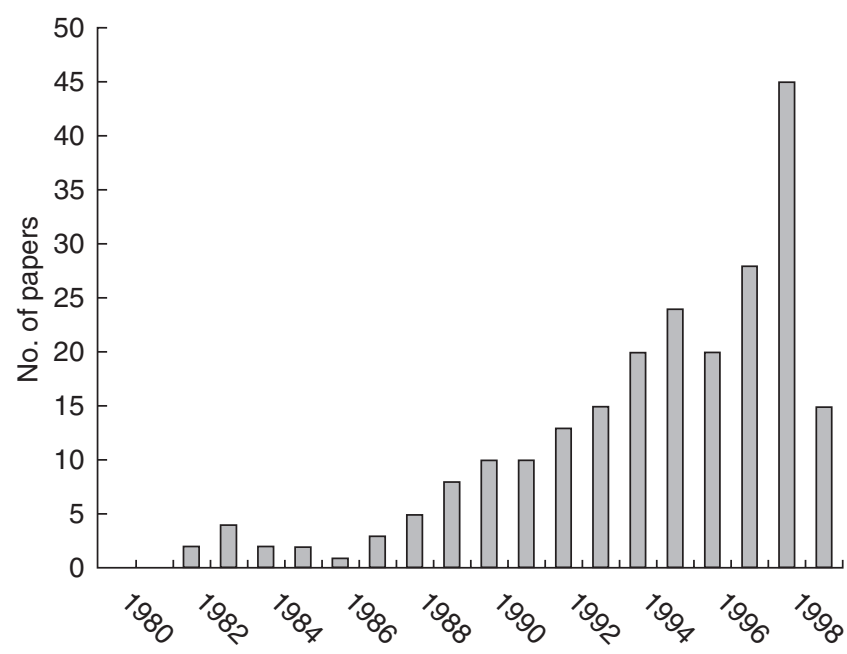

Fig. 1. Number of validation studies published by year.

example, $\mathrm{Ca}$, fruit and vegetables). A large majority (110) of the FFQ were intended to measure group or population levels of intakes, a further fifty-one stated they were intended to measure absolute intakes and fifty-eight were intended to rank individuals. Some FFQ were used to measure food patterns or to generate patterns of foods rather than nutrients (Brewer et al. 1987; Randall et al. 1989; Kant et al. 1991; Frank et al. 1992; Millen et al. 1996; Barrett et al. 1998; Musaiger and Abuirmeileh, 1998;
Hu et al. 1999; Tseng, 1999). It is important to consider the purpose of the questionnaire before it is designed to ensure that the questionnaire is sensitive enough to detect differences in the nutrients of interest. In general, FFQ are designed without assessing the possible need to adjust for energy intake in the analysis. If energy adjustment is needed, the FFQ should be comprehensive enough to assess energy (Margetts et al. 1995). The FFQ measured current diet in 169 studies and past diet in forty-three studies. The most common time frame for the assessment of diet was the previous 1 year.

Of the FFQ being validated, sixty-two were interviewerled and 153 were self-administered. In nine studies parents completed the FFQ on behalf of a child (Blom et al. 1989; Stein et al. 1992; Byers et al. 1993; Hammond et al. 1993; Kaskoun et al. 1994; Hirving et al. 1995; Bellu et al. 1996; Sloan et al. 1997; Omidvar et al. 1998). Proxy reporting is always subject to uncertainty and error. For example, a parent may not be aware of all the food eaten by a child, for example at school. If the parent completes the questionnaire in collaboration with the child and school or daycare staff, this may be helpful. Parents also tend to overestimate intakes of food considered 'healthy' and underestimate less 'healthy' foods (Hammond et al. 1993). The questionnaires administered to children tended to use standard portion sizes which had been developed from adult surveys. Parental reports, on the whole, do seem to be adequate for assessing a range of food and nutrient intakes in their children.

The mean sample size for validation studies was 255 (range 6-3750) subjects. The number of items on the FFQ ranged from five to 350 , with a mean of eighty-eight items. Portion sizes were specified by the researchers on eightyfive of the questionnaires. Subjects could specify their own portion size in seventy-three studies and there was no recording of portion sizes in forty-four studies. Food photographs were used in some studies to help in portion-size description (Porrini et al. 1995).

The FFQ asked about different frequency categories with a range of one to twelve divisions of time, the most common being nine categories (fifty-three studies). The range of frequency choices should reflect the time frame of interest. Both ascending and descending frequency categories were used. The format of the questions in terms of the order of the foods, either as a list or based on meals, does not appear to have a major impact on nutrient estimates from the questionnaire (Wheeler et al. 1994).

\section{Examples of frequency choices}

Frequency categories that FFQ used were:

five choices (times per d, week, month, year, rarely or never);

nine choices (never or less than once a month, one to three per month, one per week, two to four per week, five to six per week, one per d, two to three per d, four to five per d, six or more per d);

nine choices $(7,6,5,4,3,2$, or $1 \mathrm{~d}$ per week, monthly, rarely or never).

The FFQ was stated to include 'additional' questions in fifty-four studies. These included information about vita- 
min and supplement use (fourteen studies) and other foods consumed (thirteen studies).

The majority of the validated FFQ were designed to be used by the general population (173 studies). However, 32 $\%$ were specifically designed and validated for use in populations with or at risk of a particular disease. Of these, thirty-three out of seventy-two were designed for use in cancer studies (for example, Riboli \& Kaaks, 1997; Forman et al. 1999; Kroke et al. 1999) and four in individuals with risk factors related to heart disease, including hypercholesterolaemia (van Staveren et al. 1992; Ascherio et al. 1994). Other disease-specific FFQ were validated for use in studies of osteoporosis (Nelson et al. 1988; Welten et al. 1995; Blalock et al. 1998; Angbratt \& Moller, 1999), diabetes (Blom et al. 1989; Garnett et al. 1995; Riley \& Blizzard, 1995) and eye disease (Molla et al. 1993; Sloan et al. 1997). Sixty-five of the studies had an associated utilisation paper. Some FFQ have been designed to include foods which are important for different ethnic population groups (Borrud et al. 1989; Wahlqvist et al. 1991; Forsythe \& Gage, 1994; Kassam-Khamis et al. 1999).

\section{Methods used in food-frequency questionnaire validation studies}

Of the FFQ, $171(75 \%)$ were validated against another dietary assessment method (for example, Block, 1982; Block et al. 1992; Sawaya et al. 1996; Bingham, 1997; Bingham et al. 1997; Ocke et al. 1997; Field et al. 1998; Fraser et al. 1998; Hebert et al. 1998a). Forty-three (19\%) were validated against one or more biomarkers (for example, Byers et al. 1993; Feunekes et al. 1993; Tjonneland et al. 1993; Porrini et al. 1995; Bingham \& Day 1997; Johansson et al. 1998) and twenty-seven (12\%) against another method (for example, doubly labelled water or energy expenditure studies) (Kroke et al. 1999; Lindroos et al. 1999). A number of studies used adipose tissue not only to assess fatty-acid intakes but also fat-soluble-vitamin intakes (Tjonneland et al. 1993; Kardinaal et al. 1995; Godley et al. 1996).

The studies which used a weighed record as the method of comparison, collecting between 2 and $28 \mathrm{~d}$ of weighed intake are: (Riley \& Blizzard, 1995; Barikmo et al. 1998) at 2 d; Wolk et al. (1998) and Tucker et al. (1999) using $4 \times$ $7 \mathrm{~d}$ with a mode of $7 \mathrm{~d}(n$ 19). The $24 \mathrm{~h}$ recall studies used $1-28 \mathrm{~d}$ of recall with a mode of $1 \mathrm{~d}(n$ 11). Four studies used consecutive days of recall. The studies which used biomarkers measured blood (thirty-five studies) or urine (fifteen studies). Ten studies used both blood and urine (for example, Porrini et al. 1995; Bingham, 1997; Bingham \& Day, 1997; Bingham et al. 1997). Blood measures of vitamin $C$ were used in seven studies, urinary electrolytes in twelve studies and cholesterol in twelve studies. Twentythree studies used a dietary assessment method and a biomarker measure. However, it cannot be assumed that there will be a close or simple relationship between the dietary intake of a nutrient and its biomarker given, for example, variations in absorption and metabolism.

Comparison between methods to assess measurement differences in the validation studies used correlation coefficients in $83 \%$ (168) studies. This method is flawed because it does not measure the agreement between two methods, only the degree to which the methods are related. Correlation coefficients can be useful in conjunction with the Bland-Altman method which assesses in graphical form the agreement between the methods across the range of intakes by plotting the mean of the two methods against the difference (Bland \& Altman, 1986). The validation studies showed that the Bland-Altman comparison was carried out in only a small number of studies (Thompson \& Margetts, 1993; Rothenberg, 1994; Saba et al. 1995; Robinson et al. 1996; Lambe et al. 1998; Molgaard et al. 1998; Thompson et al. 1998). The other main approaches used were the Kappa statistic and Student's $t$ test. Twentyfive studies did not state the statistical method used for comparison and twenty-eight studies did not use the four main methods of analysis. However, correlation and regression can be useful in assessing validity. Alternatively, methods which take into account the measurement error associated with FFQ may be particularly useful, such as structural equation modelling (Kaaks et al. 1994). Some FFQ have error variances higher than the true variation and there is also a tendency for errors of measurement of different nutrients to be highly correlated (Day et al. 2001). Regression can be used to calibrate one method compared with another (Gullberg \& Elmstahl, 1994; Carroll et al. 1996). Correlation or regression should not be used alone to assess validity, but should be used alongside the Bland-Altman analysis (Bland \& Altman, 1986, 1995, 1999). However, since correlation coefficients were used as the only method of comparing measurement differences in the majority of studies, these have been assessed by the present review and compared in a number of ways.

Table 2 shows the mean correlations for a range of nutrients from those studies where an FFQ was compared against another method. The mean correlation was highest for $\mathrm{Ca}$ and total fat and lowest for vitamin $\mathrm{A}$ and vegetable intake. Vegetable intakes and related nutrients such as vitamin A are particularly difficult to assess using an FFQ. Questionnaires tend to have long lists of a wide range of vegetables that may or may not include vegetables consumed as part of mixed dishes. It is possible that misreporting of vegetables can occur for a number of reasons such as the double counting of items or social desirability bias (Calvert et al. 1997). The ability of a questionnaire to assess nutrients will vary according to the nutrient. Correlations between the reference method and FFQ may be good for total energy but poor for vitamin A (O'Brien \& Nelson, 1992; Grootenhuis et al. 1995). The present review included all papers that had involved the validation of any FFQ, without first passing judgement on the quality of the questionnaire. Therefore, it is not surprising that the comparison of different FFQ with various alternative dietary reference methods gave a range of results. It should not be assumed that one questionnaire will be equally suitable for assessment of all nutrients.

When different dietary assessment reference methods were compared there was little difference in the correlation coefficient between the different reference measures for energy, fat, vitamin $\mathrm{A}$ and $\mathrm{Ca}$. The highest correlation for energy using a weighed intake in a study of Norwegian adolescents was 0.87 (Frost Andersen et al. 1995). The 
Table 2. Mean correlations between food-frequency questionnaire and reference method

\begin{tabular}{llccc}
\hline & $n$ & Range of correlations & Mean correlation & Median correlation \\
\hline Total fat & 86 & -0.16 to 0.86 & 0.51 & 0.51 \\
Energy & 77 & -0.14 to 0.92 & 0.47 & 0.46 \\
Vitamin C & 73 & 0.14 to 0.84 & 0.49 & 0.50 \\
Vitamin A & 58 & 0.03 to 0.83 & 0.39 & 0.37 \\
Ca & 63 & 0.20 to 0.89 & 0.55 & 0.56 \\
Fe & 41 & 0.08 to 0.83 & 0.45 & 0.47 \\
Fruit & 16 & -0.01 to 0.71 & 0.49 & 0.51 \\
Vegetables & 17 & 0.16 to 0.72 & 0.39 & 0.38 \\
\hline
\end{tabular}

lowest correlation for energy with a weighed intake was 0.21 (Bell et al. 1999). This was for a study of a Samoan population living in New Zealand. It cannot be assumed that the lowest correlation represented a poor FFQ. In fact, Bell et al. (1999) concluded that the FFQ gave a better estimate of usual intake in this population than the weighed intake. This suggests that for this population at least the weighed intake may not have been an appropriate reference method. For Fe and vitamin $\mathrm{C}$ a higher correlation coefficient was found using the weighed record compared with the unweighed record or $24 \mathrm{~h}$ recall (Table 3 ).

\section{Design issues in validation studies}

The size of the validation study did not make an appreciable difference, on average, to the study results. The present review showed that correlation coefficients comparing the FFQ with a reference method were no higher for larger validation study sample sizes than smaller studies.

The issue of how portion sizes were assessed by the FFQ was considered. Correlation coefficients were highest when subjects were able to describe their own portion size compared with no portion size specified (use of average portion weights to compute intakes) or portion size specified on the questionnaire. There was little difference between no portion size specified and whether a portion size was specified (Table 4).

Portion sizes were specified by the researchers in eightyfive of the questionnaires. This presupposes knowledge about portion sizes in the population of interest. If portion sizes are unknown this information may need to be collected separately. In one study which collected portion sizes, the amounts typically consumed differed by $50 \%$ or more from published 'standard' portion weights for more than one-third of the foods considered (Conn et al. 1994). There were also differences in portion weights between men and women and by age group and socio-economic status. For most foods the variation in portion size within indi- viduals exceeded that between individuals. It may be appropriate to use sex-specific 'typical' portion weights rather than 'standard' portions to estimate nutrient intake from frequency data.

The method of administration of the FFQ in validation studies was assessed. Of the questionnaires validated, $67 \%$ were self-administered. Correlation coefficients (interviewer $v$. self-administered) between FFQ and reference measures were higher for interviewer-administered questionnaires than self-administered questionnaires for fat $(0.55$ v. 0.50$)$, energy $(0.55 v .0 .46)$, and vitamin A $(0.47 v$. $0 \cdot 37)$. Correlation coefficients were similar for $\mathrm{Ca}(0.56 v$. $0.55)$ and slightly higher for self-administered questionnaires for vitamin $\mathrm{C}(0 \cdot 45$ v. $0 \cdot 49)$. The use of interviewers may be an advantage in some situations and allows for immediate checking by the interviewer of improbable or unlikely responses. Against this is the cost of employing interviewers, ensuring standardised training processes and their presence may increase the likelihood of social desirability bias in responses from subjects.

Telephone administration of an FFQ has been carried out and compared with face-to-face interviewing. The results obtained were comparable. However, both these studies were carried out in the USA where telephone ownership is particularly high (Schaffer et al. 1997; Lyu et al. 1998). Telephone interviews have been used to supplement missing data collected from questionnaires administered by mail (Caan et al. 1991).

Most validation studies included men and women. Four studies with correlations presented included just men (Bakkum et al. 1988; Pietinen et al. 1988; Feskanich et al. 1994; Jain et al. 1996). Sixteen studies presenting correlations used only women (for example, Martin-Moreno et al. 1993; Arnold et al. 1995; Robinson et al. 1996; Friis et al. 1997; Martin et al. 1997; Baumgartner et al. 1998; Hernandez-Avila et al. 1998; Wirfalt et al. 1998; Patterson et al. 1999). The studies that had used only men showed slightly higher mean correlations for fat $(0.49 v .0 \cdot 46)$ and

Table 3. Mean correlation coefficients for food-frequency questionnaire compared against different reference methods

\begin{tabular}{lcccc}
\hline Nutrient & Weighed record $(n)$ & Unweighed record $(n)$ & 24 h recalls $(n)$ & Biomarkers $(n)$ \\
\hline Energy & $0.47(29)$ & $0.47(29)$ & $0.48(23)$ & $0.51(14)$ \\
Fat & $0.51(36)$ & $0.52(22)$ & $0.49(22)$ & $0.54(16)$ \\
Vitamin C & $0.50(27)$ & $0.46(18)$ & $0.41(20)$ & $0.46(15)$ \\
Vitamin A & $0.39(23)$ & $0.38(13)$ & $0.39(16)$ & $0.35(13)$ \\
Ca & $0.54(23)$ & $0.53(15)$ & $0.54(22)$ & $0.53(8)$ \\
Fe & $0.51(16)$ & $0.41(10)$ & $0.43(15)$ & $0.51(8)$ \\
\hline
\end{tabular}


Table 4. Correlation coefficients comparing food-frequency questionnaire and reference measure: portion-size description

\begin{tabular}{lccc}
\hline Nutrient & Describe own portion size $(n)$ & No portion size specified $(n)$ & Portion size specified $(n)$ \\
\hline Energy & $0.54(31)$ & $0.44(9)$ & $0.42(31)$ \\
Fat & $0.57(35)$ & $0.42(12)$ & $0.47(31)$ \\
Vitamin C & $0.53(28)$ & $0.45(10)$ & $0.46(29)$ \\
Vitamin A & $0.45(23)$ & $0.21(5)$ & $0.37(26)$ \\
Ca & $0.61(23)$ & $0.49(8)$ & $0.53(28)$ \\
Fe & $0.53(14)$ & $0.38(5)$ & $0.40(20)$ \\
\hline
\end{tabular}

energy $(0.42$ v. 0.38$)$ compared with the studies that only included women. However, somewhat lower mean correlations were seen for men $v$. women for vitamin C $(0.45 v$. $0 \cdot 51)$ and vitamin A $(0 \cdot 29$ v. $0 \cdot 43)$. These results imply a possible differential misclassification for men and women using an FFQ compared with another reference method. (The numbers of results were too small to break this down further by type of reference method used.)

The length of the reference period for the FFQ (for current-use questionnaires) was explored. FFQ asking for recall over the previous month had slightly higher correlations with the reference method than those recalling over the previous year. A small number of questionnaires were designed to measure nutrient intake in the past. Correlations with a reference method were similar for these questionnaires compared with FFQ designed to assess current intake. The studies which have used FFQ to assess diet a number of years ago suggest that caution is required. An FFQ may not be suitable for recalling diet in the distant past (Sobell et al. 1989; Fraser et al. 1998). The recall of past diet by FFQ is strongly related to the report of current dietary intake by FFQ (Thompson et al. 1990). A study comparing FFQ recall ability between cancer cases and controls did not find any statistically significant differences after controlling for factors that may be related to recall ability (Lindsted \& Kuzma, 1989). This suggests that although the recall of past diet may be inaccurate, there may not be any bias between those with and without disease. However, there may be other factors such as age, sex and education which affect recall of diet by FFQ (Wilkens et al. 1992).

The number of items on an FFQ did seem to affect the correlation coefficients. FFQ with the highest number of items had somewhat higher correlation coefficients than those with the smallest number of items. (For example, the top quartile of items $v$. the lowest quartile of items: fat 0.53 v. 0.47 ; vitamin $C 0.50$ v. $0 \cdot 46$.) Although a number of the shorter questionnaires were assessing single nutrients such as $\mathrm{Ca}$, many of the longer questionnaires were also assessing a single nutrient. For example, questionnaires with eight items (Angbratt \& Moller, 1999), nine items (Nelson et al. 1988), fifteen items (Blalock et al. 1998), forty or ninety-eight items (Brown \& Griebler, 1993) have all been designed to assess $\mathrm{Ca}$ intake. The study by Brown \& Griebler (1993) looked at two versions of a modified Block questionnaire and found that the short (forty-item) FFQ provided reliable estimates of usual Ca intake in milligrams and captured more than $75 \%$ of the Ca intake measured by the long (ninety-eight-item) FFQ. The shortest questionnaire had five items relating to fruit and vegetable intake
(Kristal et al. 1998) and the longest questionnaire had 350 items plus a booklet with 120 photographs to estimate portion sizes (Riboli et al. 1997a). This underlines the fact that FFQ are all different.

How foods are organised on questionnaires may have an impact on the ease of completion for subjects. One study found that subjects preferred to be asked about food intake using a questionnaire arranged by meal rather than broad food group (Boutron et al. 1989). However, foods tend to be organised on FFQ in terms of food groups.

Correlation coefficients were compared for newly designed FFQ and those adapted from other questionnaires. Newly developed questionnaires had a higher correlation for energy $(0.49 v .0 \cdot 44)$ and fat $(0.52 v .0 \cdot 49)$ than modified questionnaires. Adapted questionnaires had a higher correlation for vitamin $\mathrm{C}(0.50$ v. 0.44$)$ and vitamin $\mathrm{A}(0.41 \mathrm{v}$. $0 \cdot 34)$ than newly developed questionnaires. There were no differences (new $v$. adapted) for $\mathrm{Ca}(0.54 v .0 .55)$ and $\mathrm{Fe}$ $(0 \cdot 45$ v. $0 \cdot 44)$.

\section{Repeatability studies}

The issue of whether an FFQ can produce repeatable or reproducible results is important for all types of study design. Repeatability is generally assessed by administering the same FFQ twice to the same group of subjects and analysing the association between the two responses.

The repeatability of dietary intake was assessed in 107 of the validation studies $(45 \%)$, the most common time interval between repeat measures being 1 year. One study looked at the long-term reproducibility of diet, with repeat measures 15 years apart (Thompson et al. 1990). The shortest time interval for repeating the questionnaire was $2 \mathrm{~h}$ (Frank et al. 1992). In $34 \%$ the repeat administration was between 1 and 6 months later. Correlation coefficients were used to compare the differences between repeated measures in $90 \%$ of studies. Less than $10 \%$ used the Bland-Altman method. The difference in absolute intakes was assessed in $39 \%$ of studies.

In general, correlation coefficients were higher in repeatability studies when subjects were allowed to specify their own portion sizes. The repeatability of commonly consumed foods tends to be better than that for less commonly consumed items (Wiecha et al. 1994). The season of repeating the questionnaire appears to have little impact on the results (Hartman et al. 1996).

When the FFQ is repeated in relation to disease outcome, this can affect the results. It is not possible to distinguish real differences in reported intakes from differences in reporting of intakes and so apparent associations that may 
be found in a case-control study cannot necessarily be attributed to real dietary differences (Bunn 1993). One study explored fat intake in relation to the risk of breast cancer using repeated dietary questionnaires administered both before and after the diagnosis of breast cancer. A baseline FFQ was completed by all subjects. Breast cancer cases and age-matched controls were sent another FFQ in 1989 inquiring about their diet in 1985. Age-adjusted analysis using the prospective (1986) questionnaire demonstrated no association between breast cancer incidence and intakes of total fat (odds ratio (OR) between the highest and lowest quintiles of $0 \cdot 87 ; 95 \%$ CI $0.54,1.40$ ) and saturated fat (OR 0.97; CI 0.64, 1.46). Age-adjusted analysis using the retrospective (1989) questionnaire suggested positive associations between breast cancer incidence and intakes of total fat (OR 1.43; $95 \%$ CI $0.90,2 \cdot 27)$ and saturated fat (OR 1.38; $95 \%$ CI $0 \cdot 89,2 \cdot 13$ ). Adjustment for total energy intake gave similar results. These findings suggest that case-control studies of diet and breast cancer using retrospective FFQ may yield biased associations between fat intake and the risk of breast cancer (Giovannucci et al. 1993).

Correlation coefficients between two administrations of an FFQ of 0.5 to 0.7 are common. Repeat administrations of the FFQ at 1 month or less tended to give higher correlation coefficients than repeat administrations further apart (Table 5). Random error assessed by repeat administrations of an FFQ seems to only moderately attenuate observed diet-disease relationships; i.e., an observed OR of 1.5 and a correlation coefficient of 0.70 yield an unattenuated OR of 2.1 (Bueno de Mesquita et al. 1992).

The repeatability of nutrient intakes estimated using semi-quantitative FFQ has been shown to be high in the elderly. Older subjects may be more established in their dietary habits than younger subjects, so any tendency for repeatability to decrease due to impaired memory associated with advanced age is offset by a lower intra-individual variability in dietary habit (Nelson et al. 1988; Lazarus et al. 1995). Individuals with a stable diet, those with a vegetarian diet, and those with more education, are able to recall their past dietary practices with reasonable reliability (Kuzma \& Lindsted, 1990; Stevens et al. 1996). Repeatability studies in minority population groups were in the range usually reported in evaluations of the performance of questionnaires in non-minority populations $(0 \cdot 5-0 \cdot 8)$ (Shea et al. 1991; Coates \& Monteilh, 1997). However, some studies in the USA have found higher correlation coefficients between repeated FFQ for white Americans compared with AfricanAmericans (Stevens et al. 1996).

Most repeatability studies have used subjects who are reporting their own intakes. One study showed good

Table 5. Correlation coefficient by time interval between repeat administrations of the food-frequency questionnaire

\begin{tabular}{lccc}
\hline Nutrient & 1 month or less & 1 to 6 months & 6 months to 1 year \\
\hline Energy & 0.68 & 0.67 & 0.60 \\
Fat & 0.68 & 0.63 & 0.57 \\
Vitamin C & 0.60 & 0.64 & 0.54 \\
Vitamin A & 0.60 & 0.64 & 0.54 \\
Ca & 0.67 & 0.70 & 0.55 \\
\hline
\end{tabular}

test-retest reliability for parents reporting on behalf of their preschool children (Treiber et al. 1990). Repeated FFQ have been obtained from proxy reporters of diet for the second occasion. In one study, husbands were questioned about their deceased wife's food intake with limited success (Hislop et al. 1992). The repeatability of dietary patterns rather than simply nutrients has been assessed in a study using a sub-sample of the Health Professionals Follow-up Study (Hu et al. 1999). Their findings indicated a reasonable reproducibility of the major dietary patterns defined by factor analysis with data from their FFQ.

In nutrition-intervention research, it is important to consider the sensitivity of dietary assessment instruments to the changes in nutrient intake or dietary behaviour under study. This aspect of repeatability has been called 'responsiveness' and is an index of an instrument's sensitivity to change. Illustrations of this measure from two randomised dietary-intervention trials that targeted reductions in fat intake, the Women's Health Trial and the Eating Patterns Study, suggest that short, inexpensive measures such as FFQ or questionnaires that assess dietary habits can be as responsive as multiple-day diet records (Kristal et al. 1994). It is suggested that intervention studies should include at least two types of dietary assessment tools and the reliability and responsiveness of these tools should be reported as part of the study outcome (Kristal et al. 1994).

\section{Utilisation studies}

A total of 179 publications were identified which had used FFQ and were published in 1998. These were 156 singlestudy reports and eight groups of studies, making a total of 164 studies. Of these studies, forty-eight had been adapted from a previous FFQ, including nine from Block and ten from Willett questionnaires. Sixty-one of the studies were carried out in the USA, twenty-five in the UK, thirty-one from the rest of Europe and six from Australia and New Zealand.

The FFQ used in these studies were similar in design to those used in the validation studies. The mean number of items on the FFQ was ninety-nine. In eighty-eight of the studies, the FFQ was designed to assess current diet, most commonly over 1 year. Ninety-nine of the studies used selfadministered FFQ. The FFQ were most commonly used in cross-sectional surveys (eighty-three studies).

Associated validation papers were mentioned in ninetyone of the 164 studies. Of these, eighteen referred to the Willett FFQ as the basis for the questionnaire and twenty referred to the Block-National Cancer Institute FFQ. Results were rarely modified as a result of a validation study. For example, FFQ data were cross-checked against food-diary data. Validity was accepted if correlation coefficients were $>0 \cdot 4$ (Samaras et al. 1998).

The presentation of results sometimes included the adjustment of nutrients for total energy intakes using regression techniques (Attili et al. 1998; Curhan et al. 1998; Franceschi et al. 1998; Giovannucci et al. 1998; Vachon et al. 1998). These methods allow comparison of nutrients to be made between groups independent of the effect of different energy intakes. The ability to carry this out presupposes that the questionnaire is comprehensive 
enough to determine energy intake. Under-reporting, particularly of energy, can be a problem in dietary assessment studies. Energy adjustment appears to minimise the bias generated by under-reporting with respect to particular nutrients and their association with various disease outcomes (Gnardellis et al. 1998).

Of the FFQ, ninety-three were stated to be disease-specific, and thirty-six of them were designed to assess risks associated with cancers. A list of the diseases or conditions which FFQ were used to assess and associated references are shown in Table 6. Their uses have ranged from assessing diet in studies of various types of cancer to diet and cognitive function. A qualitative assessment of each tool has not been made. In order to assess quality there are a number of aspects which need to be considered, including whether there is an associated validation paper and whether the tool has been validated in the population on which it is being used. Even if a previous study has validated the FFQ, it should not be assumed that the tool will be applicable in all situations. An in-depth exploration of this issue is outside the scope of the present review. Nevertheless, for example, for the eight papers relating to breast cancer only three had reported previous published validation studies, which were not necessarily undertaken on a similar population to which the tool was currently being applied.

\section{Conclusion}

The FFQ is a useful tool for assessing diet in a number of different types of study. Specific design and validation issues have been highlighted by the present review. If these issues are taken into account in future research, this should improve the quality of the data collected. It is important to remember that there is no standard FFQ. Each questionnaire should be judged for its ability to provide the information for which it was intended. The consensus document has made recommendations (see Appendix) which should be considered when planning and analysing studies utilising an FFQ technique in order to optimise its performance.

\section{Acknowledgements}

The study was supported by the Ministry of Agriculture, Fisheries and Food (MAFF project no. AN0850).

Table 6. Diseases and references for disease-specific food-frequency questionnaires (FFQ)

Which diseases are FFQ

designed for? Reference

Cancer (general)

Breast cancer

Colon and colorectal cancer

Lung cancer

Oesophageal cancer, nasopharyngeal cancer

Oral leukoplakia

Ovarian cancer

Cervical dysplasia

Prostate cancer

Renal cell cancer

Stomach cancer

Non-Hodgkin's lymphoma

CHD

Blood pressure

Cardiovascular disease

Hypercholesterolaemia
Ajani et al. (1998); Caderni et al. (1998); Chatenoud et al. (1998); Gnardellis et al.

(1998); Grievink et al. (1998); Heerstrass et al. (1998); Jorga et al. (1998); Talamini et al. (1998); Voorrips et al. (1998); Voss et al. (1998)

Ambrosone et al. (1998); Cade et al. (1998); De Stefani et al. (1998a); Hebert et al. (1998b); Potischman et al. (1998b); Rohan et al. (1998); Thorand et al. (1998); Zhang et al. (1998)

Baron et al. (1998); Braga et al. (1998); Chen et al. (1998); De Stefani et al. (1998e); Franceschi et al. (1997, 1998); Glanz et al. (1998); Hyman et al. (1998); Keku et al. (1998); Negri et al. (1998); Singh \& Fraser (1998); Slattery et al. (1998)

De Stefani et al. (1998b); Garcia-Closas et al. (1998); Jatoi et al. (1998); Sinha et al. (1998)

Brown et al. (1998); Farrow et al. (1998); De Stefani et al. (1999)

Gupta et al. (1998)

Webb et al. (1998)

Kantesky et al. (1998); Wideroff et al. (1998)

Bairati et al. (1998); Giovannucci et al. (1998); Hartman et al. (1998); Schuurman et al. (1998)

De Stefani et al. (1998d); Yuan et al. (1998)

Galanis et al. (1998); Ji et al. (1998)

De Stefani et al. (1998c)

Almendingen et al. (1998); Hu et al. (1998); Kitamura et al. (1998); Swinburn et al. (1998); Thorand et al. (1998); Tzonou et al. (1998)

Dwyer et al. (1998)

Cox \& Whichelow (1998)

Romero et al. (1998) 
Table 6. Continued

Which diseases are FFQ

designed for?

Bone health

Osteoporosis

Renal stones

Appendicitis

Cerebral palsy

Cognitive function

Type 2 diabetes, diabetic eye disease, insulin resistance

Drug use

Dental caries

Gallstones

Helicobacter pylori

Hansen's disease

Hyperemesis

Fe status

Low birth weight

Maculopathy

Menopause

Multiple sclerosis

Neural-tube defects

Respiratory disease

Rheumatic fever

Rheumatoid arthritis

Ventilatory function
Reference

Melhus et al. (1998); New et al. (1998b)

Patton et al. (1998)

Curhan et al. (1998); Hirvonen et al. (1998); Leonetti et al. (1998); Sowers et al. (1998)

Naaeder \& Archampong (1998)

Petridou et al. (1998)

Munger et al. (1998); Paleologos et al. (1998)

Kao et al. (1998); Liu et al. (1998); Millen et al. (1998)

Himmelgreen et al. (1998)

Arnadottir et al. (1998)

Attili et al. (1998)

Malaty et al. (1998)

Oh et al. (1998)

Signorello et al. (1998)

Al-Othman et al. (1998)

Santos et al. (1998)

Shoff et al. (1998)

Nagata et al. (1998)

Ghadirian et al. (1998)

Shaw et al. (1998)

Fluge et al. (1998)

Zaman et al. (1998)

New et al. (1998a); Volker et al. (1998)

Carey et al. (1998)

\section{References}

Ajani UA, Cook NR, Hebert P, Lee I, Manson J, Buring J \& Hennekens C (1998) Alcohol consumption and incidence of malignant neoplasms: the Physicians' Health Study. American Journal of Epidemiology 147, S45.

Ajani UA, Willett WC \& Seddon JM (1994) Reproducibility of a food frequency questionnaire for use in ocular research. Eye Disease Case-Control Study Group. Investigative Ophthalmology and Visual Science 35, 2725-2733.

Almendingen K, Trygg K \& Pedersen JI (1998) Dietary related risk factors for coronary heart disease among male cooks. Scandinavian Journal of Nutrition/Naringsforskning 42, 69-73.

Al-Othman AM, Belton NR \& Kirk TR (1998) Iron intake and iron status in young children in Edinburgh. Proceedings of the Nutrition Society $\mathbf{5 7}, 134 \mathrm{~A}$.

Ambrosone CB, Freudenheim JL, Sinha R, Graham S, Marshall JR, Vena JE, Laughlin R, Nemoto T \& Shields PG (1998) Breast cancer risk, meat consumption and N-acetyltransferase (NAT2) genetic polymorphisms. International Journal of Cancer 75, $825-830$.

Angbratt M \& Moller M (1999) Questionnaire about calcium intake: Can we trust the answers? Osteoporosis International 9, 220-225.

Arnadottir IB, Rozier RG, Saemundsson SR, Sigurjons H \& Holbrook WP (1998) Approximal caries and sugar consumption in Icelandic teenagers. Community Dentistry and Oral Epidemiology 26, 115-121.

Arnold JE, Rohan T, Howe G \& Leblanc M (1995) Reproducibility and validity of a food-frequency questionnaire designed for use in girls age 7 to 12 years. Annals of Epidemiology 5, 369-377.

Ascherio A, Willett WC, Rimm EB, Giovannucci EL \& Stampfer MJ (1994) Dietary iron intake and risk of coronary disease among men. Circulation 89, 969-974.

Attili AF, Scafato E, Marchioli R, Marfisi RM \& Festi D (1998) Diet and gallstones in Italy: the cross-sectional MICOL results. Hepatology 27, 1492-1498. 
Bairati I, Meyer F, Fradet Y \& Moore L (1998) Dietary fat and advanced prostate cancer. Journal of Urology 159, 1271-1275.

Bakkum A, Bloemberg B, van Staveren WA, Verschuren M \& West CE (1988) The relative validity of a retrospective estimate of food consumption based on a current dietary history and a food frequency list. Nutrition and Cancer 11, 41-53.

Baranowski T, Smith M, Baranowski J, Wang DT, Doyle C, Lin LS, Hearn MD \& Resnicow K (1997) Low validity of a sevenitem fruit and vegetable food frequency questionnaire among third-grade students. Journal of the American Dietetic Association 97, 66-68.

Barikmo L, Torheim LE, Hatloy A \& Oshaug A (1998) Development and validation of a quantitative frequency questionnaire to use for an assessment of dietary intake in a rural population in Mali. European Journal of Clinical Nutrition 52, Suppl. 2, S67.

Baron JA, Sandler RS, Haile RW, Mandel JS, Mott LA \& Greenberg ER (1998) Folate intake, alcohol consumption, cigarette smoking, and risk of colorectal adenomas. Journal of the National Cancer Institute 90, 57-62.

Barrett JH, Draper A, Calvert C \& Cade J (1998) Identifying patterns of food consumption among women in the UK Women's Cohort Study: preliminary results. Proceedings of the Nutrition Society 57, 66A.

Basch CE, Shea S \& Zybert P (1994) The reproducibility of data from a food frequency questionnaire among low-income Latina mothers and their children. American Journal of Public Health 84, 861-864.

Baumgartner KB, Gilliland FD, Nicholson CS, McPherson RS, Hunt WC, Pathak DR \& Samet JM (1998) Validity and reproducibility of a food frequency questionnaire among Hispanic and non-Hispanic white women in New Mexico. Ethnicity and Disease 8, 81-92.

Bell AC, Swinburn BA, Amosa H, Scragg R \& Sharpe SJ (1999) Measuring the dietary intake of Samoans living in New Zealand: comparison of a food frequency questionnaire and a 7 day diet record. Asia Pacific Journal of Clinical Nutrition 8 , 149-154.

Bellu R, Riva E, Ortisi MT, De Notaris R, Santini I \& Giovannini M (1996) Validity of a food frequency questionnaire to estimate mean nutrient intake of Italian school children. Nutrition Research 16, 197-200.

Bingham SA (1997) Dietary assessments in the European prospective study of diet and cancer (EPIC). European Journal of Cancer Prevention 6, 118-124.

Bingham SA \& Day NE (1997) Using biochemical markers to assess the validity of prospective dietary assessment methods and the effect of energy adjustment. American Journal of Clinical Nutrition 65, 1130S-1137S.

Bingham SA, Gill C, Welch A, Cassidy A, Runswick SA, Oakes S, Lubin R, Thurnham DI, Key TJ, Roe L, Khaw KT \& Day NE (1997) Validation of dietary assessment methods in the UK arm of EPIC using weighed records, and 24-hour urinary nitrogen and potassium and serum vitamin $\mathrm{C}$ and carotenoids as biomarkers. International Journal of Epidemiology 26, Suppl. 1, S137-S151.

Blalock SJ, Currey SS, DeVellis RF, Anderson JJB, Gold DT \& Dooley MA (1998) Using a short food frequency questionnaire to estimate dietary calcium consumption: a tool for patient education. Arthritis Care and Research 11, 479-484.

Bland JM \& Altman DG (1986) Statistical methods for assessing agreement between two methods of clinical measurement. Lancet i, 307-310.

Bland JM \& Altman DG (1995) Comparing methods of measurement: why plotting difference against standard method is misleading. Lancet 346, 1085-1087.
Bland JM \& Altman DG (1999) Measuring agreement in method comparison studies. Statistical Methods in Medical Research 8 , $135-160$.

Block G (1982) A review of validations of dietary assessment methods. American Journal of Epidemiology 115, 492-505.

Block G, Hartman AM, Dresser CM, Carroll MD, Gannon J \& Gardner L (1986) A data-based approach to diet questionnaire design and testing. American Journal of Epidemiology 124, 453-469.

Block G, Thompson FE, Hartman AM, Larkin FA \& Guire KE (1992) Comparison of two dietary questionnaires validated against multiple dietary records collected during a 1-year period. Journal of the American Dietetic Association 92, 686-693.

Blom L, Lundmark K, Dahlquist G \& Persson LA (1989) Estimating children's eating habits. Validity of a questionnaire measuring food frequency compared to a 7-day record. Acta Paediatrica Scandinavica 78, 858-864.

Borrud LG, McPherson RS, Nichaman MZ, Pillow PC \& Newell GR (1989) Development of a food frequency instrument: ethnic differences in food sources. Nutrition and Cancer 12, 201-211.

Boutron MC, Faivre J, Milan C, Lorcerie B \& Esteve J (1989) A comparison of two diet history questionnaires that measure usual food intake. Nutrition and Cancer 12, 83-91.

Braga C, La Vecchia C, Franceschi S, Negri E, Parpinel M, Decarli A, Giacosa A \& Trichopoulos D (1998) Olive oil, other seasoning fats, and the risk of colorectal carcinoma. Cancer $\mathbf{8 2}$, 448-453.

Brewer ER, Kassim N, Cronin FJ, Dennis BH, Kuczmarski RJ, Haynes S \& Graves K (1987) Food group system of analysis with special attention to type and amount of fat - methodology. Journal of the American Dietetic Association 87, 584-592.

Brown JL \& Griebler R (1993) Reliability of a short and long version of the block food frequency form for assessing changes in calcium intake. Journal of the American Dietetic Association 93, 784-789.

Brown LM, Swanson CA, Gridley G, Swanson GM, Silverman DT, Greenberg RS, Hayes RB, Schoenberg JB, Pottern LM, Schwartz AG, Liff JM, Hoover R \& Fraumeni JF Jr (1998) Dietary factors and the risk of squamous cell esophageal cancer among black and white men in the United States. Cancer Causes and Control 9, 467-474.

Bueno de Mesquita HB, Smeets FW, Runia S \& Hulshof KF (1992) The reproducibility of a food frequency questionnaire among controls participating in a case-control study on cancer. Nutrition and Cancer 18, 143-156.

Bunn JY (1993) Reliability of a food-frequency questionnaire used to estimate dietary exposure to n-nitroso and related compounds in a case-control study of childhood brain tumors. Dissertation Abstracts International 53, 5666.

Burema J, van Staveren WA \& van den Brandt PA (1988) Validity and reproducibility. In Manual on Methodology for Food Consumption Studies, pp. 171-181 [ME Cameron and WA van Staveren, editors]. Oxford: Oxford University Press.

Byers T, Trieber F, Gunter E, Coates R, Sowell A, Leonard S, Mokdad A, Jewell S, Miller D \& Serdula M (1993) The accuracy of parental reports of their children's intake of fruits and vegetables: validation of a food frequency questionnaire with serum levels of carotenoids and vitamins $\mathrm{C}, \mathrm{A}$, and $\mathrm{E}$. Epidemiology 4, 350-355.

Caan B, Hiatt RA \& Owen AM (1991) Mailed dietary surveys: response rates, error rates, and the effect of omitted food items on nutrient values. Epidemiology 2, 430-436.

Cade J, Thomas E \& Vail A (1998) Case-control study of breast cancer in south east England: nutritional factors. Journal of Epidemiology and Community Health 52, 105-110. 
Cade J, Thompson R, Burley V \& Warm D (2002) Development, validation and utilisation of food frequency questionnaires - a review. Public Health Nutrition 5, 567-587.

Caderni G, Lancioni L, Palli D, Saieva C, Trallori G, Manneschi L, Renai F, Marcoccia M, Russo A \& Dolara P (1998) A dietary trial with a short-term low-sucrose diet in an Italian population: effects on colorectal mucosal proliferation. Nutrition and Cancer 32, 159-164.

Calvert C, Cade J, Barrett JH \& Woodhouse A (1997) Using cross-check questions to address the problem of mis-reporting of specific food groups on food frequency questionnaires. UKWCS Steering Group. United Kingdom Women's Cohort Study Steering Group. European Journal of Clinical Nutrition 51, 708-712.

Carey IM, Strachan DP \& Cook DG (1998) Effects of changes in fresh fruit consumption on ventilatory function in healthy British adults. American Journal of Respiratory and Critical Care Medicine 158, 728-733.

Carroll RJ, Freedman LS \& Hartman AM (1996) Use of semiquantitative food frequency questionnaires to estimate the distribution of usual intake. American Journal of Epidemiology 143, 392-404.

Chalmers I \& Altman DG (1995) Systematic Reviews. London: BMJ Publishing.

Chatenoud L, Tavani A, La Vecchia C, Jacobs DR Jr, Negri E, Levi F \& Franceschi S (1998) Whole grain food intake and cancer risk. International Journal of Cancer 77, 24-28.

Chen M-J, Longnecker MP, Morgenstern H, Lee ER, Frankl HD \& Haile RW (1998) Recent use of hormone replacement therapy and the prevalence of colorectal adenomas. Cancer Epidemiology, Biomarkers and Prevention 7, 227-230.

Coates RJ \& Monteilh CP (1997) Assessments of food-frequency questionnaires in minority populations. American Journal of Clinical Nutrition 65, 1108S-1115S.

Conn JA, Rutishauser IHE \& Wheeler CE (1994) Portion size data for foods consumed by a randomly selected sample of Geelong adults. Australian Journal of Nutrition and Dietetics 51, 58-65.

Cox BD \& Whichelow MJ (1998) Seasonal fruit consumption in relation to the development of, or death from, cardiovascular disease. Proceedings of the Nutrition Society 57,61A.

Curhan GC, Willett WC, Speizer FE \& Stampfer MJ (1998) Beverage use and risk for kidney stones in women. Annals of Internal Medicine 128, 534-540.

Day NE, McKeown N, Wong MY, Welch A \& Bingham S (2001) Epidemiological assessment of diet: a comparison of a 7-day diary with a food frequency questionnaire using urinary markers of nitrogen, potassium and sodium. International Journal of Epidemiology 30, 309-317.

De Stefani E, Deneo-Pellegrini H, Mendilaharsu M \& Ronco A (1998a) Essential fatty acids and breast cancer: a case-control study in Uruguay. International Journal of Cancer 76, 491-494.

De Stefani E, Deneo-Pellegrini H, Mendilaharsu M \& Ronco A (1999) Diet and risk of cancer of the upper aerodigestive tract I. Foods. Oral Oncology 35, 17-21.

De Stefani E, Deneo-Pellegrini H, Mendilaharsu M, Ronco A \& Carzoglio JC (1998b) Dietary sugar and lung cancer: a casecontrol study in Uruguay. Nutrition and Cancer 31, 132-137.

De Stefani E, Fierro L, Barrios E \& Ronco A (1998c) Tobacco, alcohol, diet and risk of non-Hodgkin's lymphoma: a case-control study in Uruguay. Leukemia Research 22, 445-452.

De Stefani E, Fierro L, Mendilaharsu M, Ronco A, Larrinaga MT, Balbi JC, Alonso S \& Deneo-Pellegrini H (1998d) Meat intake, 'mate' drinking and renal cell cancer in Uruguay: a case-control study. British Journal of Cancer 78, 1239-1243.

De Stefani E, Mendilaharsu M \& Deneo-Pellegrini H (1998e)
Sucrose as a risk factor for cancer of the colon and rectum: a case-control study in Uruguay. International Journal of Cancer 75, 40-44.

Dwyer JH, Dwyer KM, Scribner RA, Sun P, Li L, Nicholson LM, Davis IJ \& Hohn AR (1998) Dietary calcium, calcium supplementation, and blood pressure in African American adolescents. American Journal of Clinical Nutrition 68, 648-655.

Eck LH, Klesges LM \& Klesges RC (1996) Precision and estimated accuracy of two short-term food frequency questionnaires compared with recalls and records. Journal of Clinical Epidemiology 49, 1195-1200.

Farrow DC, Vaughan TL, Berwick M, Lynch CF, Swanson GM \& Lyon JL (1998) Diet and nasopharyngeal cancer in a low-risk population. International Journal of Cancer 78, 675-679.

Feskanich D, Marshall J, Rimm EB, Litin LB \& Willett WC (1994) Simulated validation of a brief food frequency questionnaire. Annals of Epidemiology 4, 181-187.

Feunekes GI, van Staveren WA, De Vries JH, Burema J \& Hautvast JG (1993) Relative and biomarker-based validity of a food-frequency questionnaire estimating intake of fats and cholesterol. American Journal of Clinical Nutrition 58, 489-496.

Field AE, Colditz GA, Fox MK, Byers T, Serdula M, Bosch RJ \& Peterson KE (1998) Comparison of 4 questionnaires for assessment of fruit and vegetable intake. American Journal of Public Health 88, 1216-1218.

Fluge O, Omenaas E, Eide GE \& Gulsvik A (1998) Fish consumption and respiratory symptoms among young adults in a Norwegian community. European Respiratory Journal 12, 336-340.

Forman MR, Zhang J, Nebeling L, Yao SX, Slesinski MJ, Qiao YL, Ross S, Keith S, Maher M, Giffin C, Barrett M, Taylor PR \& Graubard BI (1999) Relative validity of a food frequency questionnaire among tin miners in China: 1992/93 and 1995/96 diet validation studies. Public Health Nutrition 2 , 301-315.

Forsythe HE \& Gage B (1994) Use of a multicultural food-frequency questionnaire with pregnant and lactating women. American Journal of Clinical Nutrition 59, 203S-206S.

Franceschi S, Favero A, La Vecchia C, Negri E, Conti E, Montella M, Giacosa A, Nanni O \& Decarli A (1997) Food groups and risk of colorectal cancer in Italy. International Journal of Cancer 72, 56-61.

Franceschi S, Favero A, Parpinel M, Giacosa A \& La Vecchia C (1998) Italian study on colorectal cancer with emphasis on influence of cereals. European Journal of Cancer Prevention 7, Suppl. 2, S19-S23.

Frank GC, Nicklas TA, Webber LS, Major C, Miller JF \& Berenson GS (1992) A food frequency questionnaire for adolescents: defining eating patterns. Journal of the American Dietetic Association 92, 313-318.

Fraser GE, Lindsted KD, Knutsen SF, Beeson WL, Bennett H \& Shavlik DJ (1998) Validity of dietary recall over 20 years among California Seventh-day Adventists. American Journal of Epidemiology 148, 810-818.

Friis S, Kruger KS, Stripp C \& Overvad K (1997) Reproducibility and relative validity of a self-administered semiquantitative food frequency questionnaire applied to younger women. Journal of Clinical Epidemiology 50, 303-311.

Frost Andersen L, Nes M, Lillegaard IT, Sandstad B, Bjorneboe G-E \& Drevon CA (1995) Evaluation of a quantitative food frequency questionnaire used in a group of Norwegian adolescents. European Journal of Clinical Nutrition 49, 543-554

Galanis DJ, Kolonel LN, Lee J \& Nomura A (1998) Intakes of selected foods and beverages and the incidence of gastric cancer among the Japanese residents of Hawaii: a prospective study. International Journal of Epidemiology 27, 173-180. 
Garcia-Closas R, Agudo A, Gonzalez CA \& Riboli E (1998) Intake of specific carotenoids and flavonoids and the risk of lung cancer in women in Barcelona, Spain. Nutrition and Cancer 32, 154-158.

Garnett SP, Truswell AS \& Bonney MA (1995) Validation of a one-week food frequency questionnaire in adolescents with insulin dependent diabetes. Australian Journal of Nutrition and Dietetics 52, 29-35.

Ghadirian P, Jain M, Ducic S, Shatenstein B \& Morisset R (1998) Nutritional factors in the aetiology of multiple sclerosis: a casecontrol study in Montreal, Canada. International Journal of Epidemiology 27, 845-852.

Giovannucci E, Rimm EB, Wolk A, Ascherio A, Stampfer MJ, Colditz GA \& Willett WC (1998) Calcium and fructose intake in relation to risk of prostate cancer. Cancer Research 58, 442-447.

Giovannucci E, Stampfer MJ, Colditz GA, Manson JE, Rosner BA, Longnecker M, Speizer FE \& Willett WC (1993) A comparison of prospective and retrospective assessments of diet in the study of breast cancer. American Journal of Epidemiology 137, 502-511.

Glanz K, Kristal AR, Tilley BC \& Hirst K (1998) Psychosocial correlates of healthful diets among male auto workers. Cancer Epidemiology, Biomarkers and Prevention 7, 119-126.

Gnardellis C, Boulou C \& Trichopoulou A (1998) Magnitude, determinants and impact of under-reporting of energy intake in a cohort study in Greece. Public Health Nutrition 1, 131-137.

Godley PA, Campbell MK, Miller C, Gallagher P, Martinson FE, Mohler JL \& Sandler RS (1996) Correlation between biomarkers of omega-3 fatty acid consumption and questionnaire data in African American and Caucasian United States males with and without prostatic carcinoma. Cancer Epidemiology, Biomarkers and Prevention 5, 115-119.

Grievink L, Smit HA, Ocke MC, van't Veer P \& Kromhout D (1998) Dietary intake of antioxidant (pro)-vitamins, respiratory symptoms and pulmonary function: the MORGEN study. Thorax 53, 166-171.

Grootenhuis PA, Westenbrink S, Sie CM, de Neeling JN, Kok FJ \& Bouter LM (1995) A semiquantitative food frequency questionnaire for use in epidemiologic research among the elderly: validation by comparison with dietary history. Journal of Clinical Epidemiology 48, 859-868.

Gullberg B \& Elmstahl S (1994) Effects of imprecise measurements on relative risk assessments in nutritional studies (Meeting abstract). Proceedings / Annual Meeting of the American Association of Cancer Research 35, A1757.

Gupta PC, Hebert JR, Bhonsle RB, Sinor PN, Mehta H \& Mehta FS (1998) Dietary factors in oral leukoplakia and submucous fibrosis in a population-based case control study in Gujarat, India. Oral Diseases 4, 200-206.

Hammond J, Nelson M, Chinn S \& Rona RJ (1993) Validation of a food frequency questionnaire for assessing dietary intake in a study of coronary heart disease risk factors in children. European Journal of Clinical Nutrition 47, 242-250.

Hartman AM, Block G, Chan W, Williams J, McAdams M, Banks WL Jr \& Robbins A (1996) Reproducibility of a self-administered diet history questionnaire administered three times over three different seasons. Nutrition and Cancer 25, 305-315.

Hartman TJ, Albanes D, Pietinen P, Hartman AM, Rautalahti M, Tangrea JA \& Taylor PR (1998) The association between baseline vitamin E, selenium, and prostate cancer in the alpha-tocopherol, beta-carotene cancer prevention study. Cancer Epidemiology, Biomarkers and Prevention 7, 335-340.

Hebert JR, Hurley TG, Chiriboga DE \& Barone J (1998a) A comparison of selected nutrient intakes derived from three diet assessment methods used in a low-fat maintenance trial. Public Health Nutrition 1, 207-214.
Hebert JR, Hurley TG \& Ma Y (1998b) The effect of dietary exposures on recurrence and mortality in early stage breast cancer. Breast Cancer Research and Treatment 51, 17-28.

Heerstrass DW, Ocke MC, Bueno-de-Mesquita HB, Peeters PH \& Seidell JC (1998) Underreporting of energy, protein and potassium intake in relation to body mass index. International Journal of Epidemiology 27, 186-193.

Hernandez-Avila M, Romieu I, Parra S, Hernandez-Avila J, Madrigal H \& Willett W (1998) Validity and reproducibility of a food frequency questionnaire to assess dietary intake of women living in Mexico City. Salud Publica de Mexico 40, 133-140.

Himmelgreen DA, Perez-Escamilla R, Segura-Millan S, RomeroDaza N, Tanasescu M \& Singer M (1998) A comparison of the nutritional status and food security of drug-using and non-drugusing Hispanic women in Hartford, Connecticut. American Journal of Physical Anthropology 107, 351-361.

Hirving MA, Lawson MS, Goodhart C \& Dogan C (1995) Validation of a food frequency questionnaire in a small sample of children aged 12-24 months. Proceedings of the Nutrition Society 54, 128A.

Hirvonen T, Pietinen P, Virtanen M \& Virtamo J (1998) Diet and risk of kidney stones in a cohort of male smokers. European Journal of Clinical Nutrition 52, S80.

Hislop TG, Coldman AJ, Zheng YY, Ng VT \& Labo T (1992) Reliability of dietary information from surrogate respondents. Nutrition and Cancer 18, 123-129.

$\mathrm{Hu}$ FB, Rimm E, Smith-Warner SA, Feskanich D, Stampfer MJ, Ascherio A, Sampson L \& Willett WC (1999) Reproducibility and validity of dietary patterns assessed with a food-frequency questionnaire. American Journal of Clinical Nutrition 69, 243-249.

Hu FB, Stampfer MJ, Manson JE, Rimm EB, Colditz GA, Rosner BA, Speizer FE, Hennekens CH \& Willett WC (1998) Frequent nut consumption and risk of coronary heart disease in women. American Journal of Epidemiology 147, S70.

Hyman J, Baron JA, Dain BJ, Sandler RS, Haile RW, Mandel JS, Mott LA \& Greenberg ER (1998) Dietary and supplemental calcium and the recurrence of colorectal adenomas. Cancer Epidemiology, Biomarkers and Prevention 7, 291-295.

Jain M, Howe GR \& Rohan T (1996) Dietary assessment in epidemiology: comparison on food frequency and a diet history questionnaire with a 7-day food record. American Journal of Epidemiology 143, 953-960.

Jatoi A, Daly BD, Kramer G \& Mason JB (1998) A cross-sectional study of vitamin intake in postoperative non-small cell lung cancer patients. Journal of Surgical Oncology $\mathbf{6 8}$, 231-236.

Ji BT, Chow WH, Yang G, McLaughlin JK, Zheng W, Shu XO, Jin F, Gao RN, Gao YT \& Fraumeni JF Jr (1998) Dietary habits and stomach cancer in Shanghai, China. International Journal of Cancer 76, 659-664.

Johansson G, Akesson A, Berglund M, Nermell B \& Vahter M (1998) Validation with biological markers for food intake of a dietary assessment method used by Swedish women with three different dietary preferences. Public Health Nutrition 1, 199-206.

Jorga JB, Backovic D \& Pavlica M (1998) Selenium status of selected foods and dietary habits of cancer patients. European Journal of Clinical Nutrition 52, S24.

Kaaks R, Riboli E, Esteve J, Van Kappel AL \& van Staveren WA (1994) Estimating the accuracy of dietary questionnaire assessments: validation in terms of structural equation models. Statistics in Medicine 13, 127-142.

Kant AK, Schatzkin A, Block G, Ziegler RG \& Nestle M (1991) Food group intake patterns and associated nutrient profiles of the US population. Journal of the American Dietetic Association 91, 1532-1537. 
Kantesky PA, Gammon MD, Mandelblatt J, Zhang ZF, Ramsey E, Dnistrian A, Norkus EP \& Wright TC Jr (1998) Dietary intake and blood levels of lycopene: association with cervical dysplasia among non-Hispanic, black women. Nutrition and Cancer 31, 31-40.

Kao WHL, Brancati FL, Boland LL, Watson RL \& Puddey IB (1998) Gender differences in the association of alcohol consumption and the risk of type 2 diabetes mellitus: the atherosclerosis risk in communities (ARIC) study. American Journal of Epidemiology 147, S60.

Kardinaal AF, van't Veer P, Brants HA, van den Berg H, Van Schoonhoven J \& Hermus RJ (1995) Relations between antioxidant vitamins in adipose tissue, plasma, and diet. American Journal of Epidemiology 141, 440-450.

Kaskoun MC, Johnson RK \& Goran MI (1994) Comparison of energy intake by semiquantitative food-frequency questionnaire with total energy expenditure by the doubly labeled water method in young children. American Journal of Clinical Nutrition 60, 43-47.

Kassam-Khamis T, Nanchahal K, Mangtani P, dos Santos Silva I, McMichael A \& Anderson A (1999) Development of an interview-administered food-frequency questionnaire for use amongst women of South Asian ethnic origin in Britain. Journal of Human Nutrition and Dietetics 12, 7-19.

Keku TO, Galanko JA, Murray SC, Woosley JT \& Sandler RS (1998) Rectal mucosal proliferation, dietary factors, and the risk of colorectal adenomas. Cancer Epidemiology, Biomarkers and Prevention 7, 993-999.

Kitamura A, Iso H, Sankai T, Naito Y, Sato S, Kiyama M, Okamura T, Nakagawa Y, Iida M, Shimamoto T \& Komachi Y (1998) Alcohol intake and premature coronary heart disease in urban Japanese men. American Journal of Epidemiology 147, 59-65.

Kristal AR, Beresford SA \& Lazovich D (1994) Assessing change in diet-intervention research. American Journal of Clinical Nutrition 59, 185S-189S.

Kristal AR, Patterson RE, Simmons NC, Shattuck AS \& Beresford SA (1998) Precision and bias of food frequency questionnaire measures of fruit and vegetable intakes. European Journal of Clinical Nutrition 52, S46.

Kroke A, Klipstein-Grobusch K, Voss S, Moseneder J, Thielecke F, Noack R \& Boeing H (1999) Validation of a self-administered food-frequency questionnaire administered in the European Prospective Investigation into Cancer and Nutrition (EPIC) Study: comparison of energy, protein, and macronutuient intakes estimated with the doubly labeled water, urinary nitrogen, and repeated 24-h dietary recall methods. American Journal of Clinical Nutrition 70, 439-447.

Kuriniji N, Gensler G \& Milton R (1998) Development and validation of a food frequency questionnaire in a randomised trial of eye diseases. European Journal of Clinical Nutrition 52, Suppl. 2, S40, 1-5.

Kuzma JW \& Lindsted KD (1990) Determinants of eight-year diet recall ability. Epidemiology 1, 386-391.

Lambe J, Kearney J, Gibney MJ, LeClerq C, Beradi D, Lamberg C, Karkkainen M, Zunft HF, Sulzer S, De Henauw S \& De Volder M (1998) Use of total mean population intakes based on a 3-day diary in combination with a food frequency questionnaire to accurately predict 14-day consumer only intakes: a multi-centre study. European Journal of Clinical Nutrition 52, S50.

Lazarus R, Wilson A, Gliksman M \& Aiken J (1995) Repeatability of nutrient intakes estimated by a semiquantitative food frequency questionnaire in elderly subjects. Annals of Epidemiology 5, 65-68.

Lemaitre RN, King IB, Patterson RE, Psaty BM, Kestin M \& Heckbert SR (1998) Assessment of trans-fatty acid intake with a food frequency questionnaire and validation with adipose tissue levels of trans-fatty acids. American Journal of Epidemiology 148, 1085-1093.

Leonetti F, Dussol B, Berthezene P, Thirion X \& Berland Y (1998) Dietary and urinary risk factors for stones in idiopathic calcium stone formers compared with healthy subjects. Nephrology, Dialysis, Transplantation 13, 617-622.

Lindroos AK, Lissner L \& Sjostrom L (1999) Does degree of obesity influence the validity of reported energy and protein intake? Results from the SOS dietary questionnaire. Swedish obese subjects. European Journal of Clinical Nutrition 53, 375-378.

Lindsted KD \& Kuzma JW (1989) Long-term (24-year) recall reliability in cancer cases and controls using a 21-item food frequency questionnaire. Nutrition and Cancer 12, 135-149.

Liu J, Trevisan M \& Menotti A (1998) Alcohol consumption and insulin resistance. American Journal of Epidemiology 147, S70.

Lyu LC, Hankin JH, Liu LQ, Wilkens LR, Lee JH, Goodman MT \& Kolonel LN (1998) Telephone vs face-to-face interviews for quantitative food frequency assessment. Journal of the American Dietetic Association 98, 44-48.

Malaty HM, Graham DY, Isaksson I, Engstrand L \& Pedersen NL (1998) Co-twin study of the effect of environment and dietary elements on acquisition of Helicobacter pylori infection. American Journal of Epidemiology 148, 793-797.

Margetts BM \& Nelson M (1997) Design Concepts in Nutrition Epidemiology. Oxford Oxford: University Press.

Margetts BM, Thompson RL, Key T, Duffy S, Nelson M, Bingham S \& Wiseman M (1995) Development of a scoring system to judge the scientific quality of information from casecontrol and cohort studies of nutrition and disease. Nutrition and Cancer 24, 231-239.

Marshall JR, Lanza E, Bloch A, Caan B, Caggiula A, Quandt S, Iber F, Kikendall W, Slattery M \& Sowell A (1997) Indexes of food and nutrient intakes as predictors of serum concentrations of nutrients: the problem of inadequate discriminant validity. The Polyp Prevention Trial Study Group. American Journal of Clinical Nutrition 65, 1269S-1274S.

Martin LJ, Lockwood GA, Kristal AR, Kriukov V, Greenberg C, Shatuck AL \& Boyd NF (1997) Assessment of a food frequency questionnaire as a screening tool for low fat intakes. Controlled Clinical Trials 18, 241-250.

Martin-Moreno JM, Boyle P, Gorgojo L, Maisonneuve P, Fernandez-Rodriguez JC, Salvini S \& Willett WC (1993) Development and validation of a food frequency questionnaire in Spain. International Journal of Epidemiology 22, 512-519.

Mayer-Davis EJ, Vitolins MZ, Carmichael SL, Hemphill S, Tsaroucha G, Rushing J \& Levin S (1999) Validity and reproducibility of a food frequency interview in a multi-cultural epidemiologic study. Annals of Epidemiology 9, 314-324.

Melhus H, Michaelsson K, Kindmark A, Bergstrom R, Holmberg L, Mallmin H, Wolk A \& Ljunghall S (1998) Excessive dietary intake of vitamin A is associated with reduced bone mineral density and increased risk for hip fracture. Annals of Internal Medicine 129, 770-778.

Millen AE, Mares-Perlman J, Klein R, Klein BEK, Cruikshanks K \& Palta M (1998) Relationship of vitamins C and E to the incidence and progression of diabetic retinopathy. American Journal of Epidemiology 147, S53.

Millen BE, Quatromoni PA, Gagnon DR, Cupples LA, Franz MM, D'Agostino RB, Hunt MK, Sorensen G, Stoddard A \& Hebert J (1996) Dietary patterns of men and women suggest targets for health promotion: the Framingham nutrition studies. American Journal of Health Promotion 11, 42-53.

Molgaard C, Sandstrom B \& Michaelsen KF (1998) Evaluation of a food frequency questionnaire for assessing of calcium, protein and phosphorus intakes in children and adolescents. Scandinavian Journal of Nutrition/Naringsforskning 42, 2-5. 
Molla A, Badruddin SH, Khurshid M, Molla AM, Rahaman FN, Durrani S, Suria A, Snyder JD \& Hendricks K (1993) Vitamin A status of children in the urban slums of Karachi, Pakistan, assessed by clinical, dietary, and biochemical methods. American Journal of Tropical Medicine and Hygiene 48, 89-96.

Munger RG, Hoyt K, West N, Steffens D, Tschanz J, Norton M, Anthony J, Wyse B \& Breitner J (1998) Antioxidant intake and cognitive function in the Cache County, Utah, study of memory in ageing. American Journal of Epidemiology 147, S3.

Musaiger AO \& Abuirmeileh NM (1998) Food consumption patterns of adults in the United Arab Emirates. Journal of the Royal Society of Health 118, 146-150.

Naaeder SB \& Archampong EQ (1998) Acute appendicitis and dietary fibre intake. West African Journal of Medicine 17, 264-267.

Nagata C, Takatsuka N, Inaba S, Kawakami N \& Shimizu H (1998) Association of diet and other lifestyle with onset of menopause in Japanese women. Maturitas 29, 105-113.

Negri E, Franceschi S, Parpinel M \& La Vecchia C (1998) Fiber intake and risk of colorectal cancer. Cancer Epidemiology, Biomarkers and Prevention 7, 667-671.

Nelson M (1997) The validation of dietary assessment. In Design Concepts in Nutritional Epidemiology, pp. 241-272 [BM Margetts and M Nelson, editors]. Oxford: Oxford University Press.

Nelson M, Hague GF, Cooper C \& Bunker VW (1988) Calcium intake in the elderly: validation of a dietary questionnaire. Journal of Human Nutrition and Dietetics 1, 115-127.

New SA, Terry AR, Williams EE, Behn AR \& Gray RES (1998a) Nutrient intake and food sensitivity in patients with rheumatoid arthritis. Proceedings of the Nutrition Society 57,63A.

New SA, Tredger JA, Smith R, Greenacre MC, Grubb DA \& Reid DM (1998b) Association between present dietary intake and bone health in post-menopausal and elderly Scottish women. Proceedings of the Nutrition Society 57, 37A.

O'Brien CM \& \& Nelson M (1992) The validation of a food frequency and amount questionnaire for assessing dietary antioxidant intakes amongst older adults. Proceedings of the Nutrition Society 52, 63A.

Ocke MC, Bueno-de-Mesquita HB, Pols MA, Smit HA, van Staveren WA \& Kromhout D (1997) The Dutch EPIC food frequency questionnaire. II. Relative validity and reproducibility for nutrients. International Journal of Epidemiology 26, Suppl. 1, S49-S58.

Oh S, Paik H, Ju D, Oh SY, Paik HY \& Ju DL (1998) Dietary habits, food intake and functional outcomes in those with a history of Hansen's disease in Korea. International Journal of Leprosy 66, 34-42.

Omidvar N, Ghazi-Tabatabie M, Djazayeri A, Abassi S \& Zoghi T (1998) Validity and reliability of a short food frequency questionnaire in screening Vitamin A status of preschool children, Ilam, Iran. European Journal of Clinical Nutrition 52, Suppl. 2, $1-5$.

Paleologos M, Cumming RG \& Lazarus R (1998) Cohort study of vitamin $\mathrm{C}$ intake and cognitive impairment. American Journal of Epidemiology 148, 45-50.

Patterson RE, Kristal AR, Tinker LF, Carter RA, Bolton MP \& Agurs Collins T (1999) Measurement characteristics of the Women's Health Initiative food frequency questionnaire. Annals of Epidemiology 9, 178-187.

Patton CL, Millard PS, Kessenich CR, Storm D, Kinnicutt E \& Rosen CJ (1998) Screening calcaneal ultrasound and risk factors for osteoporosis among lesbians and heterosexual women. Journal of Women's Health 7, 909-915.

Petridou E, Koussouri M, Toupadaki N, Youroukos S, Papavassiliou A, Pantelakis S, Olsen J \& Trichopoulos D
(1998) Diet during pregnancy and the risk of cerebral palsy. British Journal of Nutrition 79, 407-412.

Pietinen P, Hartman AM, Haapa E, Rasanen L, Haapakoski J, Palmgren J, Albanes D, Virtamo J \& Huttunen JK (1988) Reproducibility and validity of dietary assessment instruments. II. A qualitative food frequency questionnaire. American Journal of Epidemiology 128, 667-676.

Porrini M, Gentile MG \& Fidanza F (1995) Biochemical validation of a self-administered semi-quantitative food-frequency questionnaire. British Journal of Nutrition 74, 323-333.

Potischman N, Caroll R \& Iturra S (1998a) Comparison of the 60and 100-item NCI-Block questionnaires with validation data. European Journal of Clinical Nutrition 52, S63.

Potischman N, Weiss HA, Swanson CA, Coates RJ, Gammon MD, Malone KE, Brogan D, Stanford JL, Hoover RN \& Brinton LA (1998b) Diet during adolescence and risk of breast cancer among young women. Journal of the National Cancer Institute 90, 226-233.

Randall E, Marshall J, Graham S \& Brasure J (1989) Frequency of food use data and the multidimensionality of diet. Journal of the American Dietetic Association 89, 1070-1075.

Research Information Systems (1999) Reference Manager, version 9. Carlsbad, CA: Institute for Scientific Information.

Riboli E, Elmstahl S, Saracci R, Gullberg B \& Lindgarde F (1997a) The Malmo Food Study: validity of two dietary assessment methods for measuring nutrient intake. International Journal of Epidemiology 26, Suppl. 1, S161-S173.

Riboli E \& Kaaks R (1997) The EPIC project: rationale and study design. European Prospective Investigation into Cancer and Nutrition. International Journal of Epidemiology 26, Suppl. 1, S6-S14.

Riboli E, Toniolo P, Kaaks R, Shore RE, Casagrande C \& Pasternack BS (1997b) Reproducibility of a food frequency questionnaire used in the New York University Women's Health Study: effect of self-selection by study subjects. European Journal of Clinical Nutrition 51, 437-442.

Riley MD \& Blizzard L (1995) Comparative validity of a food frequency questionnaire for adults with IDDM. Diabetes Care 18, 1249-1254.

Robinson S, Godfrey K, Osmond C, Cox V \& Barker D (1996) Evaluation of a food frequency questionnaire used to assess nutrient intakes in pregnant women. European Journal of Clinical Nutrition 50, 302-308.

Rohan TE, Jain M \& Miller AB (1998) Alcohol consumption and risk of benign proliferative epithelial disorders of the breast: a case-cohort study. Public Health Nutrition 1, 139-145.

Romero AL, Romero JE, Galaviz S \& Fernandez ML (1998) Cookies enriched with psyllium or oat bran lower plasma LDL cholesterol in normal and hypercholesterolemic men from Northern Mexico. Journal of the American College of Nutrition 17, 601-608.

Rothenberg E (1994) Validation of the food frequency questionnaire with the 4-day record method and analysis of 24-h urinary nitrogen. European Journal of Clinical Nutrition 48, 725-735.

Saba A, D’Amicis A \& Turrini A (1995) Evaluation of a fibre intake questionnaire using weighed records. European Journal of Clinical Nutrition 49, Suppl. 3, S135-S138.

Samaras K, Kelly PJ, Chiano MN, Arden N, Spector TD \& Campbell LV (1998) Genes versus environment. The relationship between dietary fat and total and central abdominal fat. Diabetes Care 21, 2069-2076.

Santos IS, Victora CG, Huttly S \& Carvalhal JB (1998) Caffeine intake and low birth weight: a population-based case-control study. American Journal of Epidemiology 147, 620-627.

Sawaya AL, Tucker K, Tsay R, Willett W, Saltzman E, Dallal GE \& Roberts SB (1996) Evaluation of four methods for determining energy intake in young and older women: comparison with 
doubly labeled water measurements of total energy expenditure. American Journal of Clinical Nutrition 63, 491-499.

Schaffer DM, Coates AO, Caan BJ, Slattery ML \& Potter JD (1997) Performance of a shortened telephone-administered version of a quantitative food frequency questionnaire. Annals of Epidemiology 7, 463-471.

Schuurman AG, van den Brandt PA, Dorant E \& Goldbohm RA (1998) Animal products and prostate cancer risk: results from the Netherlands cohort study after $6 \cdot 3$ years of follow-up. European Journal of Clinical Nutrition 52, S80.

Shaw GM, Todoroff KP, Selvin S \& Schaffer DM (1998) Maternal nutrient intake and risk for neural tube defect-affected pregnancies. American Journal of Epidemiology 147, S15.

Shea S, Stein AD, Lantigua R \& Basch CE (1991) Reliability of the behavioral risk factor survey in a triethnic population. American Journal of Epidemiology 133, 489-500.

Shoff SM, Newcomb PA, Mares-Perlman JA, Klein BE, Haffner SM, Storer BE \& Klein R (1998) Usual consumption of plant foods containing phytoestrogens and sex hormone levels in postmenopausal women in Wisconsin. Nutrition and Cancer 30, 207-212.

Signorello LB, Harlow BL, Wang S \& Erick MA (1998) Saturated fat intake and the risk of severe hyperemesis gravidarum. Epidemiology 9, 636-640.

Singh PN \& Fraser GE (1998) Dietary risk factors for colon cancer in a low-risk population. American Journal of Epidemiology 148, 761-774.

Sinha R, Kulldorff M, Curtin J, Brown CC, Alavanja MCR \& Swanson CA (1998) Fried, well-done red meat and risk of lung cancer in women (United States). Cancer Causes and Control 9, 621-630

Slattery ML, Boucher KM, Caan BJ, Potter JD \& Ma KN (1998) Eating patterns and risk of colon cancer. American Journal of Epidemiology 148, 4-16.

Sloan NL, Rosen D, de la Paz T, Arita M, Temalilwa C \& Solomons NW (1997) Identifying areas with vitamin A deficiency: the validity of a semiquantitative food frequency method. American Journal of Public Health 87, 186-191.

Sobell J, Block G, Koslowe P, Tobin J \& Andres R (1989) Validation of a retrospective questionnaire assessing diet 10-15 years ago. American Journal of Epidemiology 130, 173-187.

Sowers MFR, Jannausch M, Wood C, Pope SK, Lachance LL \& Peterson B (1998) Prevalence of renal stones in a populationbased study with dietary calcium, oxalate, and medication exposures. American Journal of Epidemiology 147, 914-920.

Stein AD, Shea S, Basch CE, Contento IR \& Zybert P (1992) Consistency of the Willett semiquantitative food frequency questionnaire and 24-hour dietary recalls in estimating nutrient intakes of preschool children. American Journal of Epidemiology 135, 667-677.

Stevens J, Metcalf PA, Dennis BH, Tell GS, Shimakawa T \& Folsom AR (1996) Reliability of a food frequency questionnaire by ethnicity, gender, age and education. Nutrition Research 16, 735-745.

Swinburn BA, Walter L, Ricketts H, Whitlock G, Law B, Norton R, Jackson R \& MacMahon S (1998) The determinants of fat intake in a multi-ethnic New Zealand population. Fletcher Challenge-University of Auckland Heart and Health Study Management Committee. International Journal of Epidemiology 27, 416-421.

Talamini R, Vecchia CL, Levi F, Conti E, Favero A, Franceschi S, Talamini R, Vecchia CL, Levi F, Conti E, Favero A, Franceschi S \& La Vecchia C (1998) Cancer of the oral cavity and pharynx in non smokers who drink alcohol and in non drinkers who smoke tobacco. Journal of the National Cancer Institute 90, 1901-1903.
Thompson FE, Metzner HL, Lamphiear DE \& Hawthorne VM (1990) Characteristics of individuals and long term reproducibility of dietary reports: the Tecumseh Diet Methodology Study. Journal of Clinical Epidemiology 43, 1169-1178.

Thompson RL, Little P, Barnett J \& Margetts BM (1998) The validity of dietary assessment in General Practice. European Journal of Clinical Nutrition 52, S32.

Thompson RL \& Margetts BM (1993) Comparison of a food frequency questionnaire with a 10-day weighed record in cigarette smokers. International Journal of Epidemiology 22, 824-833.

Thorand B, Kohlmeier L, Simonsen N, Croghan C \& Thamm M (1998) Intake of fruits, vegetables, folic acid and related nutrients and risk of breast cancer in postmenopausal women. Public Health Nutrition 1, 147-156.

Tjonneland A, Overvad K, Thorling E \& Ewertz M (1993) Adipose tissue fatty acids as biomarkers of dietary exposure in Danish men and women. American Journal of Clinical Nutrition 57, 629-633.

Treiber FA, Leonard SB, Frank G, Musante L, Davis H, Strong WB \& Levy M (1990) Dietary assessment instruments for preschool children: reliability of parental responses to the 24hour recall and a food frequency questionnaire. Journal of the American Dietetic Association 90, 814-820.

Tseng M (1999) Validation of dietary patterns assessed with a food-frequency questionnaire. American Journal of Clinical Nutrition 70, 422.

Tucker KL, Chen H, Vogel S, Wilson PW, Schaefer EJ \& LammiKeefe CJ (1999) Carotenoid intakes, assessed by dietary questionnaire, are associated with plasma carotenoid concentrations in an elderly population. Journal of Nutrition 129, 438-445.

Tylavsky FA \& Sharp GB (1995) Misclassification of nutrient and energy intake from use of closed-ended questions in epidemiologic research. American Journal of Epidemiology 142 342-352.

Tzonou A, Lagiou P, Trichopoulou A, Tsoutsos V \& Trichopoulos D (1998) Dietary iron and coronary heart disease risk: a study from Greece. American Journal of Epidemiology 147, 161-166.

Vachon CM, Sellers TA, Kushi LH \& Folsom AR (1998) Familial correlation of dietary intakes among postmenopausal women. Genetic Epidemiology 15, 553-563.

van Staveren WA, Feunekes GI, Elburg L \& Erdelmann F (1992) Validity of dietary questionnaires in studies on nutrition and heart disease. Bibliotheca Nutritio et Dieta 49, 47-58.

Volker DH, Major GA \& Garg ML (1998) Fat, n-6 and n-3 fatty acid intake in rheumatoid arthritis and osteoarthritis patients. Australian Journal of Nutrition and Dietetics 55, 69-73.

Voorrips LE, Goldbohm RA \& van den Brandt PA (1998) Consumption of fruit and vegetables and colorectal cancer risk: The Netherlands cohort study on diet and cancer (NLCS). American Journal of Epidemiology 147, S44.

Voss S, Kroke A, Klipstein-Grobusch K \& Boeing H (1998) Is macronutrient composition of dietary intake data affected by underreporting? Results from the EPIC-Potsdam Study. European Prospective Investigation into Cancer and Nutrition. European Journal of Clinical Nutrition 52, 119-126.

Wahlqvist ML, Kouris A, Gracey M \& Sullivan H (1991) An anthropological approach to the study of food and health in an indigenous population. Food and Nutrition Bulletin 13, 145-149.

Webb PM, Bain C, Purdie D, Harvey P \& Green A (1998) Milk consumption, galactose metabolism, and ovarian function. American Journal of Epidemiology 147, S44.

Welten DC, Kemper HC, Post GB \& van Staveren WA (1995) Comparison of a quantitative dairy questionnaire with a dietary history in young adults. International Journal of Epidemiology 24, 763-770. 
Wheeler C, Rutishauser I, Conn J \& O·Dea K (1994) Reproducibility of a meal-based food frequency questionnaire. The influence of format and time interval between questionnaires. European Journal of Clinical Nutrition 48, 795-809.

Wideroff L, Potischman N, Glass AG, Greer CE, Manos MM, Scott DR, Burk RD, Sherman ME, Wacholder S \& Schiffman M (1998) A nested case-control study of dietary factors and the risk of incident cytological abnormalities of the cervix. Nutrition and Cancer 30, 130-136.

Wiecha JM, Hebert JR \& Lim M (1994) Diet measurement in Vietnamese youth: concurrent reliability of a self-administered food frequency questionnaire. Journal of Community Health 19, 181-188.

Wilkens LR, Hankin JH, Yoshizawa CN, Kolonel LN \& Lee J (1992) Comparison of long-term dietary recall between cancer cases and noncases. American Journal of Epidemiology 136, 825-835.

Willett WC, Sampson L, Stampfer MJ, Rosner B, Bain C, Witschi J, Hennekens CH \& Speizer FE (1985) Reproducibility and validity of a semiquantitative food frequency questionnaire. American Journal of Epidemiology 122, 51-65.

Wirfalt AK, Jeffery RW \& Elmer PJ (1998) Comparison of food frequency questionnaires: the reduced Block and Willett questionnaires differ in ranking on nutrient intakes. American Journal of Epidemiology 148, 1148-1156.

Wolk A, Ljung H, Vessby B, Hunter D \& Willett WC (1998) Effect of additional questions about fat on the validity of fat estimates from a food frequency questionnaire. Study Group of MRS SWEA. European Journal of Clinical Nutrition 52, 186-192.

Yuan JM, Gago-Dominguez M, Castelao JE, Hankin JH, Ross RK \& Yu MC (1998) Cruciferous vegetables in relation to renal cell carcinoma. American Journal of Epidemiology 147, S53.

Zaman MM, Yoshiike N, Chowdhury AH, Nakayama T, Yokoyama T, Faruque GM, Rouf MA, Haque S \& Tanaka H (1998) Nutritional factors associated with rheumatic fever. Journal of Tropical Pediatrics 44, 142-147.

Zhang S, Hunter DJ, Forman MR, Rosner BA, Speizer FE \& Colditz GA (1998) Dietary carotenoids and vitamins A, C, and $\mathrm{E}$ and risk of breast cancer. American Journal of Epidemiology 147, S51.

\section{Appendix}

These are the recommendations of the consensus document (for more detail, see Cade et al. 2002).

\section{Recommendations on food-frequency questionnaire development}

\section{Questionnaire design}

Consider the following points before designing an FFQ:

Is information needed about foods, nutrients, dietary supplements, other food constituents, or specific dietary behaviours?

Is frequency of consumption required?

Is amount of consumption required?

Is information on one food or nutrient or a range required?

Is the population mean or individual intake required?

Is the absolute or relative intake needed?

Is information on dietary change required?

What level of accuracy is required?

What is the time period of interest?
What are the research constraints in terms of money, time, staff, and respondent characteristics?

Consult a statistician and nutritionist before embarking.

\section{When the use of a food-frequency questionnaire may not be appropriate}

With small numbers of subjects.

For surveillance and monitoring of current levels where accurate absolute intakes are required.

FFQ developed in one country should not be adapted for use in another country unless dietary habits are very similar.

In clinical work when precise intakes are required.

\section{Modifying existing questionnaires}

Modification of pre-existing questionnaires for use in similar populations is useful; however, the purpose of the original and new version should be carefully considered.

\section{Developing the food list}

Unless the purpose of the FFQ is very specific a comprehensive food list is desirable.

\section{Grouping of food items}

Grouping of food items should be decided a priori according to the purpose of the questionnaire.

Single items are preferable for food groups of main interest. Some grouping of single foods may need to be considered to prevent excessive questionnaire length.

\section{Closed and open questions}

If it is necessary to use open questions the questionnaire should be interviewer-administered rather than selfadministered.

\section{Estimation of portion size}

Allowing subjects to estimate their portion size is more advantageous than using average portion sizes.

Suitable methods are the use of defined small, medium and large options, and estimation of portion size using photographs.

\section{Method of administration}

If practical, interviewer-administered FFQ should be used in preference to self-administered questionnaires.

If self-administered versions are used then checking the questionnaires for completeness should be undertaken.

\section{Pre-testing of food-frequency questionnaires}

Every questionnaire should be rigorously pre-tested to ensure that the meanings of the food names and the portion-size descriptors are clear to the subjects, instructions are clear and that the method for recording responses is unambiguous. 


\section{Rejection of data from food-frequency questionnaires}

The criteria for rejection of data (cut-offs) decided $a$ priori should be stated in any publications, with the number (and percentage) of questionnaires rejected.

\section{Recommendations on tests for food-frequency questionnaire reproducibility}

Reproducibility should always be assessed.

It should be assessed in a representative sample of the target population.

The statistical methods used must take into account the purpose of the FFQ. For example, all foods and nutrients to be assessed in the main study should be assessed for reproducibility.

The interval between repeat measurements should be chosen to minimise changes over time and recall of previous answers, and will depend on the reference period of the questionnaire.

Use of the correlation coefficient for the assessment of food-frequency questionnaire reproducibility

Correlation is inappropriate to measure reproducibility.

If correlation is used, Pearson's correlation should be used for normally distributed data, and Spearman's correlation for non-normally distributed data.

\section{Use of the Bland-Altman method for the assessment of reproducibility}

The methods developed by Bland and Altman should be used to assess reproducibility and repeatability, rather than correlation.

They should be used in context and interpreted in the light of the target population and what the acceptable levels of bias and limits of agreement are in this context.

\section{Other methods for the assessment of food-frequency questionnaire reproducibility}

Kappa statistics can be used instead of the Bland-Altman method for measures involving small numbers of ordered categories.

\section{Recommendations on validation of food-frequency questionnaires}

FFQ should always be validated.

Validation studies should use similar populations to the intended main study.

The methods of validation must take into account the purpose of the FFQ. For example, all foods and nutrients to be assessed in the main study should be assessed.

Using more than one approach to validation gives added credence to the results.

\section{Sample or population selection in validation studies}

The subjects recruited for the validation study should be representative of the main study target population.
Time frame of reference method in validation studies

The period of assessment should be the same for both test and reference methods.

\section{Selection of dietary method for validation studies}

Both $24 \mathrm{~h}$ recalls and unweighed and weighed records are suitable for a reference method.

Multiple days of collection of dietary data should be undertaken.

\section{Use of biomarkers in validation studies}

Consider carefully what is being measured.

Take into account all possible errors associated with the method.

Take into consideration the relevant time frame, and the relationship between biological variation and variation in dietary intake.

\section{Correlation, regression and the Bland-Altman method in validation studies}

The methods developed by Bland and Altman should be used to measure the agreement between FFQ and other measures of dietary intake.

These methods should be used in context and interpreted in the light of the target population and what the acceptable levels of bias and limits of agreement are in this context.

Regression or correlation may be used in conjunction with the Bland-Altman method.

If correlation is used, Pearson's correlation should be used for normally distributed data, Spearman's correlation for non-normally distributed data.

Kappa and/or sensitivity, specificity, etc. may be appropriate if the data is ordered, categorical or binary.

\section{Comparison of group means within validation studies}

Group means should be assessed if absolute intakes are required.

If ranking is important, paired tests should be used, interpreting the $P$ value with caution.

The tests used should reflect the type and distribution of the data.

\section{Sample size for validation studies}

Expert statistical advice should be sought to estimate the required number of subjects.

If resources are available, higher numbers of subjects will provide better estimates of reproducibility or validity.

A sample size of at least fifty to 100 subjects for each demographic group is recommended.

\section{Sequence of administration}

The test instrument should be administered before the assessment of the reference measure. 


\section{Recommendations on description of food-frequency questionnaires in utilisation studies}

State the original objective of the questionnaire.

If the questionnaire has previously been used, give a reference.

Describe the questionnaire in terms of the number of food items and frequency choices, and how portion size has been assessed.

State whether the questionnaire was self-administered or interviewer-administered.

Describe the nutrient database used to calculate intake.
Details of reproducibility and validity that should be reported in utilisation studies

Give reference to any published validation studies.

Describe the population, sample size and reference method used.

Briefly report the results of the validation study for the foods or nutrients of interest (the results should reflect the purpose of the questionnaire).

Report any adjustments to the data (for example, use of cross-check questions).

If there has not been a validation study, give the reason. 